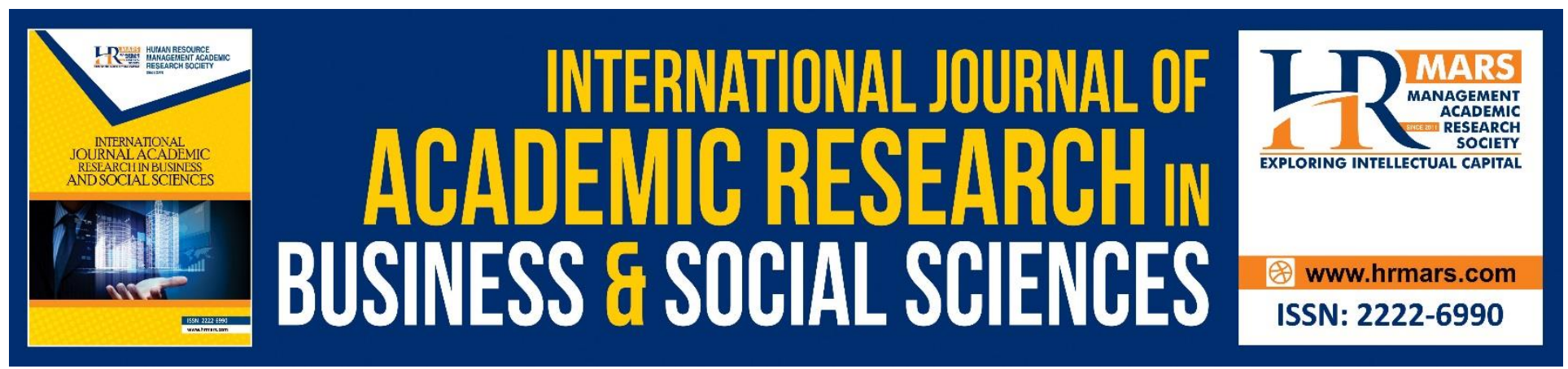

\title{
Environmental Management Support and Participation in Environmental Activities for the Well-being of Urban Community
}

\author{
Juhari Ahmad, Abdul Razaq Ahmad, Norshariani Abd Rahman \& Jalaluddin \\ Abdul Malek
}

To Link this Article: http://dx.doi.org/10.6007/IJARBSS/v8-i7/4327

DOI: 10.6007/IJARBSS/v8-i7/4327

Received: 06 June 2018, Revised: 10 July 2018, Accepted: 20 July 2018

Published Online: 30 July 2018

In-Text Citation: (Ahmad, Ahmad, Rahman, \& Malek, 2018)

To Cite this Article: Ahmad, J., Ahmad, A. R., Rahman, N. A., \& Malek, J. A. (2018). Environmental Management Support and Participation in Environmental Activities for the Well-being of Urban Community. International Journal of Academic Research in Business and Social Sciences, 8(7), 102-115.

Copyright: (C) 2018 The Author(s)

Published by Human Resource Management Academic Research Society (www.hrmars.com)

This article is published under the Creative Commons Attribution (CC BY 4.0) license. Anyone may reproduce, distribute, translate and create derivative works of this article (for both commercial and non-commercial purposes), subject to full attribution to the original publication and authors. The full terms of this license may be seen

at: http://creativecommons.org/licences/by/4.0/legalcode

Vol. 8, No. 7, July 2018, Pg. 102 - 115

http://hrmars.com/index.php/pages/detail/IJARBSS

JOURNAL HOMEPAGE

Full Terms \& Conditions of access and use can be found at http://hrmars.com/index.php/pages/detail/publication-ethics 


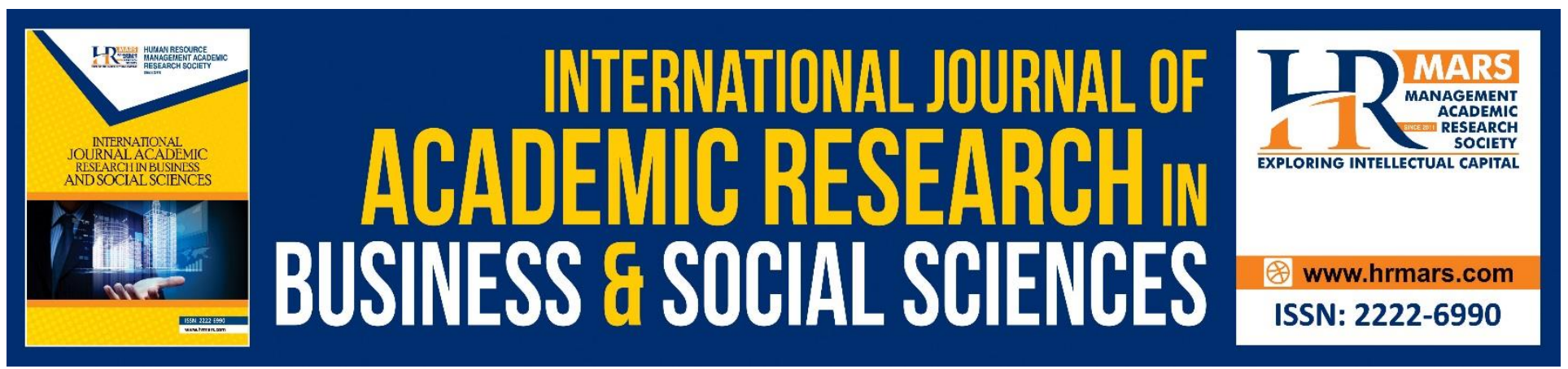

\title{
Environmental Management Support and Participation in Environmental Activities for the Well-being of Urban Community
}

\author{
Juhari Ahmad' ${ }^{1}$, Abdul Razaq Ahmad², Norshariani Abd Rahman³ \& \\ Jalaluddin Abdul Malek ${ }^{4}$ \\ $1 \& 2$ Faculty of Education, The National University of Malaysia, ${ }^{3}$ Institute of Islam Hadhari, The \\ National University of Malaysia, ${ }^{4}$ Faculty of Social Sciences and Humanities, The National University \\ of Malaysia
}

\begin{abstract}
Environmental management support as well as engagement in environmental awareness activities are imperative in ensuring the well-being of the urban community towards sustainable development. Hence, this study examines the level of environmental management support, involvement in environmental activities and the well-being of the environment based on the perceptions of urban community living in the Klang Valley and its differences based on gender and education level. This survey research uses questionnaire as research instrument. A total of 2502 respondents participated in the study, representing six Municipal Councils (MC) in the Klang Valley in Malaysia namely the Klang Municipal Council, Kajang MC, Subang Jaya MC, Selayang MC, Sepang MC and Ampang Jaya MC. Data collected involves descriptive statistics and inferential (two-way MANOVA) analysed using the SPSS version 21. The findings show that urban communities feel that the support for environmental management is moderately low while involvement in environmental activities is at a moderately high level. The well-being of the community environment is also at a moderately high level. There is no significant difference between management support, involvement in environmental activities and the well-being of the community based on gender. However, there is a significant difference in the aspect of environmental management support between the respondents who have certificate as compared to those who have diploma and degree. Respondents who have certificates felt there is less support towards environmental management as compared to those who have a diploma or a degree. Overall, this study suggests that communities need environmental management support in their residential areas in terms of environmental management facilities. In addition, environmental management activities as well as maintenance in community settings need to be enhanced in the areas of low-income urban community to achieve a well-being community as well as to ensure sustainable development.
\end{abstract}

Keywords: Environmental Management Support, Environmental Activity, Well-being of Community Environment, Environmental Care Behaviors, Sustainable Development 
INTERNATIONAL JOURNAL OF ACADEMIC RESEARCH IN BUSINESS AND SOCIAL SCIENCES

Vol. 8, No. 7, July 2018, E-ISSN: 2222-6990 @ 2018 HRMARS

\section{Introduction}

Technological advancements and rapid development in many areas today have had an impact towards lifestyle trends, thinking patterns, life statuses, social networks and various unexpected changes in the world. The effect of this development has also impacted life in Malaysia, especially among urban communities (Harris, 2012; Muhamad, 2003). Urban life is an indicator of the sustainable development framework and the society modernization process as the city is the driving force for economic activity and the migration focus for rural populations seeking for employment and seize the opportunities from the economic spillover to improve their living standards. Hence, the element of city life well-being can be a measured index in determining the progress of a country (Kartini, 2016).

A quality life involves a change in the society and the social system which starts from the awareness of each individual to adopt a healthy way of life, endeavoring to achieve every need for survival and freedom to develop individual potential. Every individual who has the same aim will form a community which work together and respect each other in the mutual surrounding environment. This atmosphere will create a sense of well-being in community (Sham, 2001). In order to achieve community well-being, a sustainable community should be formed based on the principles of sustainability which are the balances in economic, social and environment. Sustainable communities will value, preserve and conserve their inhabited environment and strive to reduce the damage towards nature which is the habitat for sustainable communities. The establishment of this sustainable community will stimulate sustainable economic growth through the provision of more competitive employment opportunities and enhance the well-being of the local community. Achieving sustainable communities requirescommitment and effort from the community members itself to be active, organized and well informed on environmental issue. Communities should also capable to inspire and aspire other communities through leadership and role model (Siti, 2010)

In this regard, the Ministry of Urban Wellbeing, Housing and Local Government hasset up a the Center of City Well-being as an initiative through the Department of Town Planning and Desa Semenanjung Malaysia to overcome urban problems such as crime rates, infectious diseases, difficulty in owning homes, traffic congestion, flash floods, water ration, vandalism and urban poverty in 2014. The issues and problems that exist in the urban community require cooperation and involvement of the top leaders, especially the Ministry of Urban Wellbeing, Housing and Local Government and members in the community to think about the creative solutions to combat urban issues. Thus, this research studies the level of support in term of environmental management, involvement in environmental activities and environmental well-being based on the perception of the urban community living in the Klang Valley. In addition, this study is also examining the differences in management support, involvement in environmental activities and environmental well-being based on gender and the level of education.

\section{Literature Review}

The well-being of a community is defined by three aspects which are the management of social problem, the fulfillment of life necessities as well as opportunities of social mobility in a community (Midgley, 1995). The existence of these three elements of well-being will provide the community with a safe environment, total access for basic needs and maximizing social mobility opportunities. Thus, 
INTERNATIONAL JOURNAL OF ACADEMIC RESEARCH IN BUSINESS AND SOCIAL SCIENCES

Vol. 8, No. 7, July 2018, E-ISSN: 2222-6990 @ 2018 HRMARS

members of the community are free to develop their own potential, actively involved in the activities conducted and contribute to the community as a whole (Midgley, 1995).

In the context of Malaysia, various community development programs conducted in order to improve the well-being of the people. Based on the Malaysia Quality of Life Report in 1999 (Economic Planning Unit, 1999), the assessment of the well-being of people comprises the aspect of selfimprovement, a healthy way of life, access and freedom to achieve knowledge, a standard of living beyond basic needs and fulfilling psychological needs to achieve the level of life wellbeing which is in par withe the aspirations of the country. When a society shifts to an atmosphere of life that is generally better, then its well-being is considered to have increased (Economic Planning Unit, 1999). Among the key indicators used in determining the well-being of life in Malaysia are income and distribution, work environment, transportation and communication, health, education, housing, environment, family life, social participation and public safety.

Studies on the well-being of the urban community have been widely conducted by researchers abroad (Roberto, 2008; Pain \& Townshend; 2002). However, the studies only focus on economic aspects without referring to environmental support and involvement in environmental activities. These factors are important in establishing a sustainable city where communities feel secure, prosperous in environmental entity, economic, value and socio-cultural that have a wellestablished connections (Sham, 2001). Hence, there is a need to study the environmental management support, involvement in environmental activities as well as the environmental wellbeing felt within the urban community.

\section{Research Methodologies \\ Research Framework}

This study is the survey research using questionnaire as an instrument. Researcch survey can generalised the reserach population. Questionnaire was used as it was a quick and fast instrument to get obtain a more accurate information from respondents and larger populations (Creswell, 2012; Konting, 2004). The usage of the questionnaire in this study was based 5 points Likert scale questionnaires as it is capable to provide various choices for the respondents and further illustrate higher continuity in the range of responses in obtaining information from the respondents (Colman, Norris \& Preston, 1997).

\section{Research Sampling}

Based on data from the Economic Planning Unit of the Prime Minister's Department (2017), the population of Selangor state is generally 6.02 million where Selangor has the highest population state as compared to other states in Malaysia. In addition, the living standard of people living in the Selangor is among the highest and the poverty rate in the country is the lowest. Based on Gross Domestic Product (GNP) per capita, Selangor is the richest state in Malaysia. This is due to the best infrastructure, such as highways and various public transport to facilitate the movement of the communities there.

The determination of the number of samples in this study was based on the sample size determination table by Krejcie and Morgan (1970) where in this study the population of Selangor is 6.02 million. If according to the sampling, a total of 344 respondents are sufficient. Respondents in 
INTERNATIONAL JOURNAL OF ACADEMIC RESEARCH IN BUSINESS AND SOCIAL SCIENCES

Vol. 8, No. 7, July 2018, E-ISSN: 2222-6990 @ 2018 HRMARS

this study were aged 25 to 40 years old, categorized as adults and mature enough to answer the questionnaire. Hence, the researchers have set the number of sample size for each place to be of 350 respondents consisting of 175 Malays, 105 Chinese and 70 Indians. Hence, the whole sample is 2100 respondents.

Sample selection was randomly stratified taking into consideration the Municipal Council around the state of Selangor as well as their gender and ethnicity of the respondents are in line with the views expressed (Cohen et al., 2007; Jorgensen, 1989). Six Municipal Councils were selected in this study namely the Klang Municipal Council, Kajang MC, Subang Jaya MC, Selayang MC, Sepang MC and Ampang Jaya MC.

\section{Research Instrument}

The questionnaire in this study is developed based on several theories such as Ecological System Theory (Bronfrenbrenner, 2005), Social Capital Theory (Putnam, 2001), Urban Wellbeing Theory (Constanza et.al, 2007) as well as literature reviews and models related to the quality and well-being of urban communities. In addition, the questionnaire was adapted from the last questionnaire by linking on some key aspects such as the quality of life and social well-being. The items for each construct in this study are as shown in Table 1.

Table 1 Items That Represent Each Research Construct

\begin{tabular}{|c|c|c|c|}
\hline No & Construct & Source of Adaptation & Item \\
\hline 1 & $\begin{array}{l}\text { Physical } \\
\text { Support in } \\
\text { Environmental } \\
\text { Management }\end{array}$ & $\begin{array}{l}\text { Ecological System Theory } \\
\text { (Bronfrenbrener, 2015) }\end{array}$ & $\begin{array}{l}\text { 1. Environmental cleanliness is } \\
\text { well kept. } \\
\text { 2. Rubbish piles are not collected. } \\
\text { 3. Non-periodic mosquitoes } \\
\text { spraying in this area. } \\
\text { 4. The landscape design in this } \\
\text { area is cheerful. } \\
\text { 5. Surrounding buildings is well } \\
\text { maintained. }\end{array}$ \\
\hline 2 & $\begin{array}{l}\text { Participation in } \\
\text { Environmental } \\
\text { Activities }\end{array}$ & $\begin{array}{l}\text { Ecological System Theory } \\
\text { (Bronfrenbrener, 2015) }\end{array}$ & $\begin{array}{l}\text { 1. I act in ensuring the } \\
\text { preservation of the } \\
\text { environment in my home } \\
\text { 2. I separate items that can be } \\
\text { recycled based on specified } \\
\text { category } \\
\text { 3. I make sure the garbage is } \\
\text { placed in the garbage dump } \\
\text { provided by the Municipal } \\
\text { Council } \\
\text { 4. I save electricity to ensure } \\
\text { environmental sustainability } \\
\text { 5. I do not litter everywhere in the } \\
\text { residential area }\end{array}$ \\
\hline
\end{tabular}




\begin{tabular}{|c|c|c|c|}
\hline 3 & $\begin{array}{l}\text { Environmental } \\
\text { Well-Being of } \\
\text { Urban } \\
\text { Community }\end{array}$ & $\begin{array}{l}\text { Urban Wellbeing Theory } \\
\text { (Constanza et.al, 2007) }\end{array}$ & $\begin{array}{l}\text { 1. I am satisfied with the } \\
\text { cleanliness in the area } \\
\text { 2. This settlement is suitable with } \\
\text { our family life well-being } \\
\text { 3. It is easy for me to get access } \\
\text { for public transport } \\
\text { 4. The greenness of surrounding } \\
\text { in my living places make me } \\
\text { feel healthier } \\
\text { 5. I am always cheerful with good } \\
\text { environment in my home. }\end{array}$ \\
\hline
\end{tabular}

Questionnaires used in this study consist of five parts. Section A relates to respondents' demographics which include the aspects of gender, ethnicity, age, residential area which refers to Municipal Council area, income and education level, while part B is related to physical support for environmental management. Part $\mathrm{C}$ refers to the participation in community-driven activities involving environmental sustainability. Part $D$ is a variable for the well-being of the urban community's living environment. Each construct contains five statements. The answer is five-point Likert scale which are very disagree, disagree, less agree, agree and very agree (Vagias, 2006).

\section{Validity and Reliability}

Before the pilot study conducted, the questionnaire was referred to three field experts (two from the Center of Higher Education who are experts in the study on the wellbeing of urban community and one from the Municipal Council in Selangor) to determine the content validity. It is important to determine each item used is in accordance with the goal of the study and can be understood by respondents. The review is to use the questionnaire format which give spaces for the expert to comment on constructs and items used. The comments are based on the suitability of the constructs, the items and also the languages used.

In addition, interviews and direct discussions with experts are also referred. After receiving detailed information and notes provided by the experts in the field, researchers have improved and modified the item as advised by the experts and discarded some items that were pointed out as inappropriate the three experts. The summary from the experts' assessment on the items of the questionnaire will be taken action such as the incompatiblity with the research aim, the clarity of the meaning as well as the overlapping statements with other item in the same construct.

After the expert reference process and the improvement of items in the questionnaire were conducted, a pilot study was conducted involving 100 respondents consisting of 40 Malays, 40 Chinese and 20 Indians in the Klang Valley. The overall results of the reliability of the pilot study for the three constructs in the study are as in Table 2. 
INTERNATIONAL JOURNAL OF ACADEMIC RESEARCH IN BUSINESS AND SOCIAL SCIENCES Vol. 8, No. 7, July 2018, E-ISSN: 2222-6990 @ 2018 HRMARS

Table 2 Questionnaire Items Reliability for Environmental Management Support, Participation in Environmental Activities and Environmental Well-being of Urban Communities

\begin{tabular}{ccccc}
\hline Construct & Item & $\begin{array}{c}\text { Item correlation } \\
\text { with the modified } \\
\text { total score }\end{array}$ & $\begin{array}{c}\text { Alpha Cronbach } \\
\text { Value if the item } \\
\text { is discarded }\end{array}$ & $\begin{array}{c}\text { Total Alpha } \\
\text { Cronbach } \\
\text { Value }\end{array}$ \\
\hline Environmental & B1 & 0.370 & 0.744 & \\
Management & B3 & 0.339 & 0.713 & 0.960 \\
Support & B5 & 0.419 & 0.840 & \\
& B6 & 0.458 & 0.913 & \\
Participation in & C1 & 0.547 & 0.954 & 0.895 \\
Environmental & C3 & 0.565 & 0.863 & \\
Activities & C4 & 0.556 & 0.863 & \\
& C5 & 0.720 & 0.811 & \\
\hline \multirow{2}{*}{ Environmental } & D2 & 0.506 & 0.878 & \\
Well-Being of & D4 & 0.557 & 0.861 & \\
Urban & D5 & 0.574 & 0.824 & \\
Community & D6 & 0.689 & 0.808 & \\
\hline
\end{tabular}

\section{Data Collection Procedure}

Before conducting the research, some research procedures need to be followed. Among them is to obtain a written validation from the Faculty of Education, Universiti Kebangsaan Malaysia (UKM) to conduct research. Most of the data collection is conducted in public places as specified in sample and location selection. However, the researchers also sought cooperation with the management of the activities carried out by the Ministry of Youth and Sports to obtain consent in using some of their activities participants as respondents in this study. Similarly, to the NGOs that discretion was used to obtain the consent of getting respondents from their activities participants.

Collection of questionnaire is done directly which is helped by six enumerators for each zone. Prior to the collection of data, all of the enumerators were briefed on the method of distributing the questionnaire so that the questionnaire distributed could be answered completely by the respondents. The administration of questionnaires was conducted directly with the respondents. Each respondent who answered the questionnaire was given a souvenir of a small notebook as a token of appreciation from the researcher.

\section{Data Analysis}

This study uses the process of analyzing data involving two types of statistics ie descriptive statistics and inference. Descriptive analysis involves percentages of respondents' backgrounds which are gender and academic level as well as the value of mean score for each of the construct involved. The mean interpretation in this study is adaptation from Nunnally (1997) as 
INTERNATIONAL JOURNAL OF ACADEMIC RESEARCH IN BUSINESS AND SOCIAL SCIENCES Vol. 8, No. 7, July 2018, E-ISSN: 2222-6990 @ 2018 HRMARS

shown in Table 3. Inference analysis involves two way MANOVA to compare environmental management support, involvement in environmental activities and the well-being of the urban community environment. Before MANOVA's analysis was carried out, revisions were made to the data normality, isolated data, linearity, homogeneity of regressions, multicolinearity and singularity and homoscedascity to fulfill the MANOVA analysis assumption (Hair et al., 2010).

Table 3 Mean Score Interpretation

\begin{tabular}{cc}
\hline Scale Range & $\begin{array}{c}\text { Mean Score } \\
\text { Interpretation }\end{array}$ \\
\hline $1.00-2.00$ & Low \\
$2.01-3.00$ & Moderately Low \\
$3.01-4.00$ & Moderately High \\
$4.01-5.00$ & High \\
\hline
\end{tabular}

Source : Nunnaly (1997)

\section{Research Findings}

\section{Demographics of Respondents}

Table 4 shows the demographics of respondents involved in this study. The 1149 respondents were male and 1353 respondents were female. Of these respondents, 1154 had certificate qualification, 864 had diploma and 484 had degree.

Table 4 Demographics of Respondents

\begin{tabular}{cccc}
\hline Profil & Demographics & Frequency & Percentage \\
\hline Gender & Male & 1149 & 46.0 \\
& Female & 1353 & 54.0 \\
Level of & Certificate & 1154 & 44.0 \\
Education & Diploma & 864 & 35.4 \\
& Degree & 484 & 12.8 \\
& & & \\
\hline
\end{tabular}

The Level of Environmental Management Support, Participation in Environmental Activities and Environmental Well-Being of Urban Community

Research findings show that the respondents perceived environmental management support in community was at medium low. Meanwhile the respondents' participation in environmental activities and environmental well-being of urban community at medium high level. The summary of the findings is demonstrated in Table 5. 
INTERNATIONAL JOURNAL OF ACADEMIC RESEARCH IN BUSINESS AND SOCIAL SCIENCES

Vol. 8, No. 7, July 2018, E-ISSN: 2222-6990 @ 2018 HRMARS

Table 5 The Level of Environmental Management Support, Participation in Environmental Activities and Environmental Well-Being of Urban Community

\begin{tabular}{lllll}
\hline No & Construct & Mean & $\begin{array}{l}\text { Standard } \\
\text { Deviation }\end{array}$ & $\begin{array}{l}\text { Mean } \\
\text { Interpretation }\end{array}$ \\
\hline 1 & $\begin{array}{l}\text { Environmental } \\
\text { Management } \\
\text { Support }\end{array}$ & 2.36 & 0.34 & Medium Low \\
2 & $\begin{array}{l}\text { Participation in } \\
\text { Environmental } \\
\text { Activities } \\
\text { Environmental Well- } \\
\text { Being of Urban } \\
\text { Community }\end{array}$ & 3.75 & 0.65 & Medium High \\
\hline
\end{tabular}

Comparison among Environmental Management Support, Participation in Environmental Activities and Environmental Well-Being of Urban Community Based on Gender and Level of Education

Three factors were measured i.e. environmental management support, participation in environmental activities and environmental well-being of urban community. Before carrying out the MANOVA analysis, M' Box test was conducted to determine the variance-covariance difference in the dependent variables for all the independent variables. Test results from the $\mathrm{M}^{\prime}$ Box showed that there was no significant difference in variance-covariance among the dependent variables for all the independent variables. This meant that the variance-covariance was homogenous in the dependent variables across all the independent variables. Similarly, Levene's test showed that all variables had the same variance; thus, the MANOVA analysis was considered appropriate.

The results of the MANOVA analysis showed that there were significant differences between the environmental management support and the level of education with Wilks' Lambda value $=.991$; $F(6,4988)=3.883, p=.000(p<.05)$ and partial eta squared $=.005 \eta^{2}$ showed that $5 \%$ of the variance was attributed to environmental management support by level of education. The effect size was small (Cohen, 1988). However, there were no significant differences between the participation in environmental activities and environmental well-being of urban community bandar based on gender and the interaction between gender and the level of education. A summary of the findings is shown in Table 6. 
INTERNATIONAL JOURNAL OF ACADEMIC RESEARCH IN BUSINESS AND SOCIAL SCIENCES Vol. 8, No. 7, July 2018, E-ISSN: 2222-6990 (C) 2018 HRMARS

Table 6 Comparison of Two-Way MANOVA Analysis on Environmental Management Support, Participation in Environmental Activities and Environmental Well-Being of Urban Community based on Gender and Level of Education

\begin{tabular}{|c|c|c|c|c|c|c|c|}
\hline Groups & $\mathbf{N}$ & $\begin{array}{c}\text { Wilks' } \\
\text { Lambda } \\
\text { Value }\end{array}$ & $\mathbf{F}$ & $\begin{array}{c}\text { Df } \\
\text { between } \\
\text { group }\end{array}$ & $\begin{array}{l}\text { Df within } \\
\text { group }\end{array}$ & Sig. & $\begin{array}{c}\text { Partial } \\
\eta^{2}\end{array}$ \\
\hline $\begin{array}{l}\text { Male } \\
\text { Female }\end{array}$ & $\begin{array}{l}1149 \\
1353\end{array}$ & .998 & 1.337 & 3 & 2494 & .261 & .002 \\
\hline Sijil & 1154 & .991 & 3.883 & 6 & 4990 & $.001^{*}$ & .005 \\
\hline Diploma & 864 & & & & & & \\
\hline ljazah & 484 & & & & & & \\
\hline \multicolumn{2}{|c|}{ Gender\#Education } & .977 & 1.262 & 6 & 4988 & .271 & .002 \\
\hline
\end{tabular}

\# interaction

*significant at level< .05

The test of between-subject effects presented in Table 7 showed that significant difference was found for environmental management support based on the level of education, as indicated by the level of the Alpha Bonferroni value $(.05 / 3)=.017$. Comparison analysis was repeated using the Bonferroni Alpha modifications to avoid type I error (Hair et al. 2010).

Table 7 Test of Between-Subject Effects on the Environmental Management Support, Participation in Environmental Activities and Environmental Well-Being of Urban Community Based On Level of Education

\begin{tabular}{llllll}
\hline Construct & Groups & $\begin{array}{l}\text { Score } \\
\text { Mean }\end{array}$ & $\mathbf{F}$ & Sig. (p) & Partial $\boldsymbol{\eta}^{\mathbf{2}}$ \\
\hline Environmental & Certificate & 2.396 & 6.649 & $.001^{*}$ & .005 \\
Management Support & $\begin{array}{l}\text { Diploma } \\
\text { Degree }\end{array}$ & $\begin{array}{l}2.343 \\
2.398\end{array}$ & & & \\
& & & & & \\
Participation in & Certificate & 3.688 & 2.691 & .068 & .002 \\
Environmental & Diploma & 3.734 & & & \\
Activities & Degree & 3.629 & & & \\
& & & & & \\
Environmental Well- & Certificate & 3.694 & 2.720 & .066 & .002 \\
Being of Urban & Diploma & 3.760 & & & \\
Community & Degree & 3.749 & & & \\
\hline
\end{tabular}

*significant at level<.017

Scheffe's post-hoc test was conducted to identify the differences in environmental management support based on the level of education. As can be observed in Table 6, there were significant differences between the respondents who had certificate and respondent with Diploma and Degree. Based on the mean value (in Table 7), respondents who had diploma were less perceived environmental management support compared to the respondents who had diploma and degree. 
INTERNATIONAL JOURNAL OF ACADEMIC RESEARCH IN BUSINESS AND SOCIAL SCIENCES

Vol. 8, No. 7, July 2018, E-ISSN: 2222-6990 @ 2018 HRMARS

Table 8 Scheffe's Post - Hoc Results of Multiple Comparisons of Environmental Management Support Based on Level of Education.

\begin{tabular}{lllccc}
\hline $\begin{array}{l}\text { Dependent } \\
\text { Variable }\end{array}$ & $\begin{array}{l}\text { (I) Level of } \\
\text { Education }\end{array}$ & $\begin{array}{l}\text { (J) Level of } \\
\text { Education }\end{array}$ & $\begin{array}{c}\text { Mean } \\
\text { Difference }(I- \\
\mathrm{J})\end{array}$ & Std. Error & Sig. \\
\hline Environmental & Certificate & Diploma & $.0552^{*}$ & .01558 & $.002^{*}$ \\
Management & & Degree & -.0027 & .01876 & .989 \\
Support & \multirow{2}{*}{ Diploma } & Certificate & $-.0552^{*}$ & .01558 & $.002^{*}$ \\
& & Degree & $-.0579^{*}$ & .01967 & $.013^{*}$ \\
& \multirow{2}{*}{ Degree } & Certificate & .0027 & .01876 & .989 \\
& & Diploma & $.0579^{*}$ & .01967 & $.013^{*}$ \\
\hline
\end{tabular}

*significant at level< .05

\section{Discussion}

The findings show that the urban community feels that the support for environmental management is in moderately low level. Therefore, the Municipal Council needs to improve the environmental management facilities in the city resident area to assist the urban community in managing solid waste as well as creating a good behavior towards the environment. This is because environmental management services and facilities is also a contributing factor for behavior towards environment as compared to the settlements and social place (Kennedy et al., 2009). Early research in the year 80 s to 90s show that the behavior of people in the city to care for the environment is higher as compared to rural areas (Kennedy et al. 2009). However, the ease of obtaining environmental management services such as recycling facilities and lack of dependence on natural resources industries has led to the same environmental awareness between the rural and urban communities (Kennedy et al., 2009). The absence of environmental management facilities such as waste bins, recycling bins, waste disposal centers and recycling centers constitutes a constraint in demonstrating positive behavior towards the environment (Prabawa \& Baudains, 2012).

However, the involvement in environmental activities and the well-being of the community is at a moderately high level. This shows that the community has shown awareness in displaying behaviors which are responsible towards the environment. Community involvement is an alternative method to improve hygiene and health, especially in residential areas. The residents and community members also agree that their residential area fulfil their life requirements such as the access for public transport, health services, neighborhood supermarkets and facilities to get to work and leisure area. The residents are comfortable in using public public facilities as well as satisfied because their residential area provides good facilities for children's education such as the nursery and kindergarten which allow them to send their children when they go to work. These factors lead to the well-being of the community.

The findings show that there is no significant difference between the environmental management support, the involvement in environmental activities and the well-being that is felt based on the gender. This finding is difficult to predict as the females ususally displayed better better 
attitude towards the environment as they are influenced by the community (Vishwanath, 2006) and are sensitive to what is happening in their environment (Carrier 2004; Tiwi et al., 2006). This finding might indicate that the awareness towards a clean and healthy environment as well as the involvement in taking action on environmental issues have increased among people regardless of their gender. Well-being that is felt is also mutual between both females and males because the surrounding environment provided in their settlements compromised to the both needs of women and men.

Based on research finding, citizens that have certificate felt less support in environmental management as compared to respondents with Diplomas and Degrees. This finding shows that the level of education affects the sense of environmental management support. Hence, environmental management and maintenance need to be enhanced in low-income urban community areas to achieve the well-being of the community. This can be attributed to limited financial resources, lack of labor, transport vehicles and equipment. According to studies by Afrizal \& Embong (2012), the implementation of the primary collection scheme in Kota Bharu was initiated by the Local Authorities (PBT) due to their inability to provide efficient, effective and comprehensive solid waste management services because of their limited financial resources, workers, transport vehicles and operators. Higher-educated individuals have a higher income, health and number of living space as compared to those with lower education (Economic Planning Unit, 1999; Javed et al., 2008). This is a factor that causes them to experience higher environmental management supports.

However, the involvement of the community is not influenced by the level of education based on the findings of the study. This is because the changes in behavior towards environmental care require a significant amount of time (Gralton et al., 2004). The research conducted by Kollmuss \& Agyeman (2002) shows that higher education does not equate to better behavior towards environmental. However, the one that leads to better behaviour is due to the increased experience of individual involvement in environmental activity (Zarrintaj et al., 2010). Therefore, the improvement of the level of study only affects the improvement of environmental knowledge but does not affect the environmental care behaviors. Similarly, the well - being of the community is not influenced by the level of education. This indicates that the population is satisfied with the cleanliness of the surrounding area. This is in line with Muhamad (2003) which stated that the life well-being is essentially an effort to overcome the problem and improve the quality of life of a human being in a safe, healthy and comfortable environment both physically, mentally, and psychologically.

\section{Conclusion}

Facility support in environmental management provided in the residential areas can stimulate and encourage residents to engage in environmental activities. The complete facilities, with access to transportation, business areas, nearby economic activities centers and the physical condition of homes built with quality and desirable building features will make the homeowners feel calm and happy to inhabit the area as well as encourage a more exciting and enjoyable life. These factors enhance the sense of well-being in the urban community.

The unique features of a sustainable city such as a green city which is a city within a park, a smart city that leverages the technology and safe city that is free of crime and the urban residents 
INTERNATIONAL JOURNAL OF ACADEMIC RESEARCH IN BUSINESS AND SOCIAL SCIENCES

Vol. 8, No. 7, July 2018, E-ISSN: 2222-6990 @ 2018 HRMARS

that live comfortably without any worries and doubts. Hence, further studies can be made to assess the impact of sustainable urban development on the lives of urban communities in terms of social and economic life. With the increment of crime cases, environmental pollution issues, flash floods, property prices, land use aggravation and traffic congestion, hence the aspects of security, tranquillity and the sense of community in urban life now have experienced a deteriorating decline in the wellbeing of life.

Further studies can also see how the responsibility in maintaining safety, hygiene, harmony and well-being as a research dimension that can be highlighted to be one of the aspects of the study. Wellness can be viewed in a variety of perspectives and dimensions because the meaning of life wellbeing is different for each individual, so different perspectives can be highlighted in future studies. There is a myriad of aspects in sustainable urban development that can be highlighted in subsequent studies by using various variables to explore the index of the urban community wellbeing.

Overall, the surrounding environment is essential for the comfort of living in a residential area. Hence, various measures need to be taken to improve the well-being of the environment by enforcing regulations such as providing non-smoking community signage areas, regular and periodic solid waste disposal, quick and fast action to deal with vandalism that disrupt the well-being of the population. The earth summit took the pledge to bring into the economic growth and environmental wellness to ensure that the generation today could continue to enjoy the benefits from the ongoing development but also being responsible for the future generations to enjoy the same benefits.

\section{References}

Bronfenbrenner, U. (2005). The developing ecology of human development: Paradigm lost orparadigm regained. In U. Bronfenbrenner (Ed.), Making human beings human: Bioecologicalperspectives on human development (pp. 94-105). Thousand Oaks, CA: Sage.

Carrier, S. J. (2004). Gender Differences in Attitudes toward Environmental Science. School Science and Mathematics, 107(7), 271-278.

Creswell, J. (2002). Educational research: Planning, conducting, and evaluating quantitative and qualitative research. Upper Saddle River, NJ: Merrill Prentice Hall.

Colman, A. M., Norris, C. E., \& Preston, C. C. (1997). Comparing rating scales of different lengths: Equivalence of scores from 5-point and 7-point scales. Psychological Reports, 80, 355362.

Cohen, L., Manion, L. \& Morrison, K. (2007). Research methods in education. 6th edn. London: Routledge.

Gralton, A., Sinclair, M., \& Purnell, K. (2004). Changes in attitudes, beliefs and behavior: a critical review of research into the impacts of environmental education initiatives. Australian Journal of Environmental Education, 20 (2), 41-52.

Jorgensen, D. L. (1989). Participant observation: methodology for human studies. Newbury, CA: Sage.

Kartini, A. T. (2016). Konsep, dasar dan perlaksanaan Bandar Sejahtera dengan rujukan khas kepada Malaysia. GEOGRAFIA OnlineTM Malaysian Journal of Society and Space, 12 (7), 26 - 33.

Kennedy, E. H., Beckley, T. M., McFarlane, B. L., \& Nadeau, S. (2009). Rural-Urban Differences in Environmental Concern in Canada. Rural Sociology, 74(3), 309-329. 
INTERNATIONAL JOURNAL OF ACADEMIC RESEARCH IN BUSINESS AND SOCIAL SCIENCES

Vol. 8, No. 7, July 2018, E-ISSN: 2222-6990 @ 2018 HRMARS

Kollmuss, A., \& Agyeman, J. (2002). Mind The Gap: Why Do People Act Environmentally And What Are The Barriers To Environmental Behavior? Environmental Educational Research, 8 (3), 239-260.

Krejcie, R. V., dan Morgan, D. W. (1970). Determining sampel size for research activities. Educational and Psychological Measurement. 30 (3), 607-610.

Midgley, J. (1995). Social development: the development perspective in social welfare. London: Sage Publication

Konting, M. M. (2004). Kaedah penyelidikan pendidikan. Kuala Lumpur: Dewan Bahasa dan Pustaka.

Muhamad, F. N. (2003). Penilaian dampak pembangunan ke arah kesejahteraan masyarakat; penilaian dampak sosial. Utusan Publication \& Distributor, Kuala Lumpur.

Nunnally, J. C. (1997). The study of change evaluation research: principle conserning measurement experimental design and analysis. Dlm. Struening, E.L \& Guttentag, M. (pnyt). Handbook of Evaluation Research. Beverly Hills: Sage.

Pain, R., \& Townshend, T. (2002). A safer city centre for all? senses of 'community safety' in newcastle upon tyne. Geoforum 33, 105-119.

Prabawa, S. K., \& Baudains, C. (2012). Asking the participants: students' views on their environmental attitudes, behaviours, motivators and barriers. Australian Journal of Environmental Education, 27(2), 219-228.

Putnam, R. D. (2001). Social capital. measurement and consequences. Canadian Journal of Policy Research 2:41-51.

Robert, O. A. L. (2008). Progress in sustainable development research. Nova Science Publisher Inc.

Sham, S. (2001). Developing urban sustainability indicators for Malaysia. LESTARI Public Lecture, No 3. Bangi: LESTARI (UKM).

Rahman, S. F. A. (2006). Kriteria kualiti hidup berkeluarga [cited 29 November 2010]. Available from: http://www.ikim.gov.my/bm/paparmedia.php?key=781.

Afrizal, T., \& Embong, A. R. (2013). Komuniti dan pengurusan persekitaran: beberapa pengalaman malaysia, bangladesh, zambia dan vietnam. Kajian Malaysia, 31 (2): 65-86.

Tiwi, K., Noraznan, M., \& Tay, T. P. (2006). Penglibatan guru pelatih KPLI maktab perguruan batu lintang dalam amalan gaya hidup mesra alam. Jurnal Penyelidikan IPBL 7.

Unit Perancang Ekonomi, JPM. (1999). Indeks Kualiti Hidup Malaysia (MQLI). Putrajaya Perspective (Boulder, CO, West- view), pp. 8-51.

Vagias, W. M. (2006). Likert-type scale response anchors. Clemson International Institute for Tourism \& Research Development, Department of Parks, Recreation and Tourism Management. Clemson University.

Vishwanath, H. N. (2006). Model of Teaching in Environmental Education. ISBN: 8183560784. India: New Delhi. Discovery Publishing House.

Zarrintaj, A., Sharifah, Z. S. Z., Abdul, S. H., \& Mahyar, S. (2013). Relationship between awareness, knowledge and attitudes towards environmental education among secondary school students in malaysia. World Applied Sciences Journal, 22(9), 1326-1333. 